\title{
SUZANA RAJIĆ
}

University of Belgrade, Faculty of Philosophy

Department of History

srajic@f.bg.ac.rs

\section{CONSTITUTIONAL ORGANIZATION OF SERBIA AND ROMANIA IN THE 19 ${ }^{\text {th }}$ CENTURY: THE INTERNAL NEEDS AND EXTERNAL INFLUENCES - A COMPARATIVE ANALYSIS*}

\begin{abstract}
The aim of this paper is to analyze the impact of two important factors in the process of the constitutional organization of Serbia and Romania during the $19^{\text {th }}$ century: the external factors and internal socio-political circumstances. Therefore, the constitutional models, modes and types of implementation are an important part of this work. Using analytical and comparative methods, I will discuss the similarities and differences in the processes of constitutionalization in one part of the Balkans region.
\end{abstract} Politics.

Keywords: Constitutions, Parliamentary System, Serbia, Romania, Western Influences, Internal

$\mathrm{T}$

The second and third decades of the $19^{\text {th }}$ century were a period of great turmoil that engulfed the newly formed Balkan states - Romania and Serbia. In that time their political autonomy within the Ottoman Empire was established and it naturally affected the changes in internal social and political trends of the principalities. By mimicking long-lasting European institutions, with the aim of the avant-garde acting ahead of the civilized world and in a culturally authoritative world, politically immature societies tried to reach goals which were too high for them. And it is no surprise that such a path lead to an atypical occurrence of high constitutive and parliamentary norms. However, these $19^{\text {th }}$ century countries, through their own experience, founded and created many peculiarities in the constitutional, even the parliamentary system. Under the pretext of social and political immaturity, Russia on the one hand and West European countries on the other tried to strengthen their influence in the Balkans. Thus, Russia supported the rule of oligarchy, while the Western powers raised constitutional hereditary monarchies with a clear division of power and a representative government system. The dominant Russian influence in

\footnotetext{
This article is a part of the project "Srpska nacija - integrativni i dezintegrativni procesi" ("Serbian nation Integrative and Disintegrating Processes") No. 177014 supported by the Ministry of Education, Science and Technological Development of the Republic of Serbia.
} 
Serbia and the Danubian Principalities (Moldavia and Wallachia) conceded to the West after the Crimean War and Paris Peace Treaty in 1856. So the conditions were created for a the mixture of French, British and Belgian constitutional models to be implemented in the Balkan Peninsula.

The interior organization of the Balkan states since the beginnings of their emancipation from the Ottoman Empire in the early $19^{\text {th }}$ century was defined through public-legal edicts - Hatti-Sharifs. The Russian Empire was the guarantor of the autonomous status and interior organization during the first half of the $19^{\text {th }}$ century and, respectively, the Russian Emperor himself was the patron of the Orthodox population in the European part of the Ottoman Empire based on the Treaty of Kucuk Kaynarca of 1774. The Russian Empire in the $18^{\text {th }}$ century failed to realize its goal in the Balkans by means of weapons and chose to support the reconstruction of the Balkan states' statehood, regarding them as its satellites. ${ }^{1}$ The constant decline of the Ottoman Empire facilitated such plans. Due to the proximity of the river Danube, Russia put a question of independence of Wallachia and Moldavia from the Turkish government as its priority task. As a Turkish ally (1799-1806), Russia first obtained Hatti-Sharifs for Wallachia and Moldavia (1802), thus gaining administrative autonomy for those provinces and their princes could not be dismissed without Russian consent. A new Russo-Turkish war (1806-1812) brought the Russian occupation and military administration to Wallachia. In spring 1821 the Phanariot regime fell, but the uprising of Tudor Vladimirescu, who took over the political control over the country for a few weeks, was extinguished.

By the Treaty of Adrianople between Russia and the Ottoman Empire in 1829, Wallachia gained political autonomy and was under the protection of Russia until 1856. The influence that Russia had in Serbia was less straightforward. In addition to several joint operations with the Serbian rebels against Turkish troops (1807, 1810-1812), the Russian military no longer entered the territory of the Serbian state during the $19^{\text {th }}$ century, largely because of persistent insistence of Western countries, especially the Habsburg Empire which saw the area south of the Sava and Danube rivers as its sphere of influence. As in the case of the Danubian principalities, by a direct ultimatum Russia forced the Turkish authorities to issue Hatti-Sharifs to Serbia $(1829,1830$ and 1833) by which Serbia became a hereditary principality with a high degree of autonomy and the obligation to pay an annual tribute. Serbia and Romania owed their restoration of statehood to the Russian Empire. The bilateral Russian-Turkish treaties (Akkerman Convention of 1826, Treaty of Adrianople of 1829) stated obligations of the Ottoman Empire towards Serbia, Moldavia and Wallachia, followed by the sultan's edicts - Hatti-Sharifs, and the first statutes and constitutions. The Western states considered the Russian breakthrough to the Balkans dangerous to their

From the $18^{\text {th }}$ century Wallachia became a target of both Austria and Russia. The Russian Tsar Peter I issued a proclamation to the Christians in the Ottoman Empire to come under Russian protection. This venture collapsed after the defeat on the river Prut in 1711. Austria had much more success, occupying the Small Wallachia in the period from 1716 to 1739. In the Russo-Turkish War (1768-1774) Wallachia was occupied by the Russian troops and the Russian military administration was imposed. In the next Austro-Russo-Turkish war in 1789-1791-2, the Austrian troops entered Wallachia once again, which facilitated the Russo-Austrian occupation. In retaliation, the Sultan sent a punitive expedition of Osman Pazvantoğlu, which ravaged the territory of Small Wallachia in 1799 and overthrew the local prince. 
interests and by joining forces they defeated the Russian Empire, imposing severe restrictive provisions in Paris in $1856 .^{2}$

The states signatories of the Paris Peace Treaty of 1856 took over the supervision of the Balkan principalities' autonomy. This meant that the Turkish vassals could not independently change their interior organization without the consent of all the signatory states (Britain, France, Habsburgs, Prussia, Kingdom of Sardinia, Russia and Turkey as a suzerain). However, it happened in the case when pro-Russian rulers Miloš Obrenović and Alexandru Ioan Cuza took over the Serbian and Romanian thrones. Western powers gave their consent and made it possible for both principalities to adopt their constitutions against the wish of Porte, although they were still formally and legally under the supreme authority of the Sultan. It was one of the ways to break away from the Russian influence. Using a nonconforming attitude of the Great Powers towards solving the Eastern Question, Serbia and Romania, on their way to the national independence, sought to independently establish their constitutional order without any external influence. The constitutional orders in Romania in 1866 and Serbia in 1869 were established as in the de facto independent states. The arrangement remained until the Congress of Berlin in 1878, when Serbia and Romania gained international recognition as independent states. This official recognition came after the Russian proposal and the provisions on the independence of Serbia, Montenegro and Romania were incorporated in the San Stefano Peace Treaty with Turkey (March 1878). From that point until the outbreak of the First World War Russia found ways to spread the so-called "moral" impact on the Balkan Christians, insisting on religious unity and Slavic togetherness.

It was a counterweight to the growing influence of the Western European liberal ideas that after the first independent constitution of the sixties increasingly spread in the Balkan Peninsula. The Balkans were seen as the 'other within', in fact as "wild Europe". Because of that, very soon after the Austrian occupation of Bosnia and Herzegovina (1878) the idea of European civilization mission on the Balkans was born. At the same time, needs of the Balkan peoples to come close to the western models grew to make them acceptable for the West and to stop pressuring their weak and unstable states. The Balkan states were not willing to replace Russian tutoring with that from the West, but they were often forced to seek protection against the growing pressures from the East looking to the West. Since in the last quarter of the $19^{\text {th }}$ century the pressure of neighbouring Habsburg Monarchy rapidly increased, they sought the support in the French and British cultural and constitutional models even more.

\section{Constitutional Beginnings}

The abolition of feudalism in Serbia in 1835 ended an extremely important period in the history of the Principality initiated by the Serbian revolution of 1804. Serbia managed to build its basic state institutions by 1835 , the government and the local authorities. It was also a leading country in the number of adopted constitutions in the $19^{\text {th }}$ century, but also in its instability and frequent changes and coups which were putting those constitutions out of force. However, from 1835 until 1929 Serbia was never in a dictatorship or functioned in

2 Vinogradov 2010: ch. 3; Ljušić 2004: 201. 
the extra-constitutional system. Of all its constitutional enterprises from the $19^{\text {th }}$ century $\left(1835,1838^{3}, 1869,1889,1901\right.$ and $\left.1903^{4}\right)$ the Constitution from 1869 was the longest in force - two decades in continuity and in the period from 1894 to 1901. At the request of the Suzerain - Porte and the patron - Russia, the first self-made Constitution of 1835 adopted by the Serbian Assembly was suspended after only three weeks. Then Russia, which at first advised Prince Miloš Obrenović to work on the adoption of the constitution, strongly protested because the imperial court was not consulted nor informed about the work on the project. The Serbian Constitution of 1835 was one of the most liberal European ones. Its provisions proclaimed the separation of powers - legislative, executive and judicial, but it did not implement it verbatim; all citizens were equal before the law; implementation of feudalism was prohibited; inviolability of personal and property rights were guaranteed; and every slave who stepped on Serbian soil was to become free. Serbia received external symbols and attributes of statehood - borders, an emblem, and a flag. However, it was true that besides Russia and Turkey, Britain, France and the Habsburg monarchy were against the constitution. In Europe this Constitution was called the "French seedling in the Serbian forest." In addition to pressures from the outside, the internal opposition to the constitution was strong and required a different division of power, which could limit the prince's power considerably and was in favour of the oligarchy which acquired some wealth, mainly by trade. ${ }^{5}$ Their few representatives, descendants of the peasant class, were considered as deserving individuals who had distinguished themselves in the struggle for national liberation during the Serbian revolution (1804-1835).

Categorical in their position that a vassal state could not be regulated by a constitution, as it had already been done by an imperial act, an absolute monarchical Hatti-Sharif, Turkey and Russia negotiated a new constitution for Serbia in 1838 and sent it in the form of the socalled Fourth Hatti-Sharif. The provisions of the Constitution of 1838 did not envisage the institution of the National Assembly and the principality was to be ruled by seventeen oligarchs gathered in the Council of State. The Prince had only executive power, while the legislative one was given to the Council of State. The Assembly had only three sessions in twenty years $(1842 / 43,1848,1858)$ on the basis of the amendment of 1839 . One third of the provisions of the Constitution spoke of the institution of the court (three instances), which was of great importance to the legal system as it was still in its infancy. In the upcoming decades Serbia made a great effort and successfully passed civil, criminal and other laws, complemented four instance court system and from 1858 the judicial power was completely separate from the other two, executive and legislative. The state devoted its great attention to the training of the staff and in 1862 the last illiterate judge in Serbia was retired. ${ }^{6}$

In the neighboring principalities, Moldavia and Wallachia, in the $1820 \mathrm{~s}$ and $1830 \mathrm{~s}$ there was also a struggle for the adoption of a constitution and for the unification of the two

3 The Constitution was adopted by the Porte as the fourth Hatti-Sharif, but Serbia did not participate in its writing. However, this Constitution was necessary for the prince's opposition (Defenders of Constitution) as it completely destroyed the power of Prince Miloš Obrenović, who abdicated already in 1839 . The Constitution of 1838 was in effect de facto by 1869 and de jure by 1861

4 This was in fact the Constitution of 1889 , which was reinstated in 1903 with slight modifications.

Ljušić 2006: 123-132.

Ljušić 2004: 174-202; Popović 2014: 165, 180, 221. 
principalities. As in Serbia, these processes were conducted under the strong influence of the two forces - the Ottoman Empire and Russia. ${ }^{7}$ In the period of the Russian military administration in Wallachia, after the Treaty of Adrianople in 1829, the two Danube principalities received the first joint constitutional act "The Organic Regulation" adopted in Bucharest in $1832 .{ }^{8}$ They served as a basis for the subsequent unification of the principalities and for the creation of the modern Romanian state. The fact is that the 'Regulations' were written by the boyars with the help of the Russian occupation power, which contributed to their extreme unpopularity. Nevertheless, the fact is that the 'Regulations' was a fundamental document, which set the foundations for the parliamentary institution in the Romanian Principalities. The principle of the separation of powers was introduced to the extent that the legislative power was exerted by both the Prince and an Ordinary National Assembly (an assembly which privileged the boyars). It also included the absolute veto on the Assembly's decisions, which was the right of the Prince. ${ }^{9}$

Free trade, the return of Braila and other ports on the Danube River under domestic administration created conditions for an economic and cultural revival of the country under Prince Alexandru II Ghika (1834-1842). Dissatisfied with him, Russia and Turkey took part in his overthrowing and a National Assembly elected Georghe Bibescu (1843-1848) as a new ruler. It was a compensation for the anti-Russian regime in Serbia under Prince Aleksandar Karađorđević (1842-1858). Under the influence of the revolutionary events in Europe in June 1848, the prince was overthrown in Romania and a provisional government was formed. The Proclamation (Islaz Proclamation) required political freedom, the National Assembly to be the main carrier of sovereignty, the state independence, the abolition of feudalism and the implementation of agrarian reform, progressive taxation and the constitution based on local laws and customs. The proclamation essentially advocated a republican form of state organization with an elected ruler who would be elected to that office every five years from the representatives of all classes. ${ }^{10}$ It was the assay to reconcile the requirements of the revolution with those of pragmatic constitutionalism. ${ }^{11}$ The constitutional project, which was created in 1848 for Moldavia by Michael de Kogalnitchan (The Project of the Moldavian Constitution) provided a constitutional monarchy, separation of powers between the executive, legislative and judicial, ministerial responsibilities, and a guarantee of the rights and duties of the citizens. In addition, it limited the prince's power, which could be taken as a prerequisite of modern constitutionalism. ${ }^{12}$

However, Turkish troops, joined by the Russian army, occupied Bucharest on 13 September 1848 and quashed the rebellion. The armies of both countries remained in Wallachia until 1851 and brought Barbu Dimitrie Stirbey to the throne (1848-1853, and 1854-1856). His power was only a titular one, as during the Crimean War in Wallachia three occupying powers alternated: Russia in 1853-1854, Turkey in 1854, and Austria in 1854-1856.

Stănescu 2007: 167-178.

A constitutional document, named 'The Organic Regulations' was adopted in Wallachia in 1831 and a year later it was implemented in Moldavia.

Stanomir 2002.

Hriscu 2010: 346-354.

Stanomir 2002: Ch. 2.

Stănescu 2007: 179; Stanomir 2002: Ch. 2. 
After these events, Europe aimed at suppressing the influence of Russia permanently and for it to be successful it was necessary to establish or hold principalities' regimes in the Balkans that could oppose the Russian imperial goals. One of the methods of influence was to support aspirations of the Serbian principality, Moldavia and Wallachia to independently decide on their respective internal organizations in the future in accordance with their needs, traditions, customs and habits. Therefore, the developed Western countries offered the principalities more advanced and more liberal patterns of internal organization, which by respecting the individual rights, quite appropriately met the young societies' needs for emancipation and made a speedy transition to the "modern and progressive" world, as they saw it, leaving the "oriental" past behind.

\section{The Constitution as a Tool of State Emancipation}

The Treaty of Paris of 1856 was supposed to form one body ad-hoc Assembly for Wallachia and Moldavia, which would be inclined to the unification of the two countries. In August 1858 the Paris Convention played the role of the constitution until 1866, but it did not formally recognize the unification. There were two rulers, two governments, two Judicial Assemblies, but also some common institutions such as the Central Committee, High Court of Cassation and Justice. The local elites were unsatisfied with the way of achieving unification. The French Constitution of 1848 was responsible for a strong Wallachian republicanism, while the Belgian Constitution of 1831 urged for a constitutional monarchy in Moldavia. Nevertheless, in January 1859 Unionists in Wallachia voted for prince Alexandri Ioan Cuza, who had already been elected as the Moldavian prince. They created a common state in the form of a personal union (Principatele Unite ale Valahiei şi Moldovei) and Bucharest became the capital and the seat of the Parliament.

All Romanian literature associated the Act of Unification (1859) and the adoption of the first Romanian Constitution in 1866 with the emergence of a modern Romanian state and Romanian modern constitutionalism. During the seven-year reign (1859-1866) Prince Cuza conducted a rapid modernization of the society by introducing civil, criminal and other laws, following primarily the French legislation. His attempt to carry out an agrarian reform (Expropriation law of 1864) and thus prevent further pauperization of the peasantry was hit by a combined resistance of the aristocracy who struggled to preserve their position. Under the accusation that it inclined towards absolutism, aristocracy organized a coup and Prince Cuza was removed. Some Romanian authors justify the coup as an achievement defending political freedom against the prince who wanted to usurp them for his own interests. ${ }^{13}$ Other authors considered the princes' ideas to be advanced as he sought to improve the position of the largest social class, the peasantry, by agrarian reforms. However, at that time the ideological conflict moved into the modern Parliament established by the Paris Convention and Prince Cuza, who installed his personal authoritarian regime after the 'coup d'état' of May 1864, was forced to abdicate in 1866 making way for the establishment of the parliamentary regime. ${ }^{14}$

\footnotetext{
Stanomir 2002: Ch. 2.

14 Laurentiu 2002: 230-231.
} 
In order to preserve their privileges the union between the liberals and the conservatives against Prince Cuza was often cited as a crucial point from which Romania continually improved its concept of the "policy of compromise". However, it is evident that not all of the social strata participated in that action; indeed, the most numerous segments of the society, the peasantry, did not participate. Although we cannot speak of a parliamentary democracy, the Constitution of 1866 set the framework and a clear structure of the separation of power so that the old autocratic methods combined with the new representative political institutions. Instead of the previously elective monarchy, Romania turned to a hereditary monarchy, which was very important for the stability and progress of the principality. The principles of national sovereignty and separation of power were adopted. The Conservatives, who were the most numerous, managed the work from the Parliament and the influence of the masses from the "bottom" was completely annulled. ${ }^{15}$ Some authors believe that after the Constitution of 1866 the Romanian society lived under a disguised authoritarian regime of Prince Carol Hohenzollern, who was constantly working to strengthen his influence in both external and internal affairs. ${ }^{16}$ For the lower classes the electoral system provided indirect voting and a limited number of voters and the most numerous social class, the peasantry, had no influence on the political life of the country. The literature also records a medium line, arguing that after adopting the Constitution Romania became a constitutional monarchy modelled after the French system and that in the referendum the newly elected German prince Karol of the Hohenzollern lineage agreed to be an arbiter in the political life as well. I can say that because of the absolute veto, which the Prince had, the ruler prevailed with regard to the representative bodies. The Prince did not cope well with the liberal demands in the Assembly, so a Senate was soon formed. It consisted almost exclusively of landowners and some intellectuals/doctors and former ministers. With the help of the Senate and the so-called 'Romanian patriots' who invited him to the throne and helped him to hold on to it, Prince Karol was able to keep the promise that he had given - to respect the Constitution. Romanian constitutional debut of 1866 was in force for more than fifty years until $1923 .{ }^{17}$ And then, in the preparation of a new constitution, almost the entire text was incorporated in the new constitutional draft. The first revision of the Constitution occurred in 1884 after a revolt of the peasants. The riots resulted in the expansion of the influence of the middle class at the expense of big landowners, while the peasants remained on the margins of political events.

The Principality of Serbia also became a hereditary constitutional monarchy by the new Constitution of 1869 in which the unicameral Parliament was an inevitable factor in the legislation, even though it had no right to initiate legislation. However, the number of those who went to polls, with a low property census of fifteen dinars a year ${ }^{18}$, was close to 300,000 of the adult male population (about $65 \%$ of adult men). In addition to the elected representatives (2/3), the category of Deputies by position (1/3) increased, whom the prince selected among the people experienced in public affairs and the few educated members of

Carp 2002.

Gutan 2013: 230-231.

Stanomir 2002: ch.2; Kellog 1995: 15-23.

Serbian dinar was equivalent to the French franc. 
the nation. ${ }^{19}$ Serbia became a constitutional monarchy with the values of European constitutionalism: representative regime, low poll tax, the separation of powers, inviolability of the monarch, the political responsibility of the government before the Assembly and the monarch, judicial independence. The Prince from the Obrenović Dynasty shared the legislative power with the Assembly, confirmed and declared the laws, had executive authority over the ministers, was the supreme commander of the army, represented the country in all international relations, but had no absolute right to veto like the Romanian ruler. With the equality of citizens before the law, the inviolability of private property, freedom of speech and the written word, the Serbian Constitution offered the highest achievements of European constitutionalism. It was a kind of compromise between the liberals and the conservatives, who called for national unity. But unlike Romania, where liberals and conservatives came from different social structures, Serbian liberals and conservatives belonged to sparse Serbian intelligentsia of peasant origin and a rare merchant class who were also recruited from the ranks of the peasantry. Five hundred deputies at the National Assembly in 1869 supported the government programme of reforms and a new constitution, which seemed to be an expression of a successful compromise. However, by the 1870s it was obvious that there was a disunity in Serbia, in the so-called national and political unity because many of the farmers' children, educated at the public expense, returned to the country bringing socialist ideas. In the 1870s they entered the Assembly and united with the peasant representatives. ${ }^{20}$ The new constitutional frameworks and a low property census enabled the masses to enter the politics and liberal laws created a favourable climate for the development of the parties. A few conservatives/progressives made a coalition with the Socialists followers who were called radicals and by joining forces they overthrew a years-long liberal government (1880). But the agreement did not last long because the progressives sought the rule of intelligentsia and a two-house parliamentary system, while the radicals had won almost $90 \%$ of the peasantry to their side for several years, who were a poorly differentiated social stratum that enjoyed economic independence, political and civil rights, but were illiterate and unqualified for the government and political affairs. The principal demands of the radicals included the general voting rights, the parliamentary constitutional order and a national state in which the representatives of the people, elected by a secret ballot, had all the power. In addition, there was a request for the decentralization of the state administration; it was clear that they aspired to reduce the right of the Crown in just a titular form. The impact of the masses and the pressure "from below", which in Romania was restrained by an agreement of the aristocracy and the urban middle class, in Serbia grew to unprecedented proportions because the peasantry was incorporated into one party, the Radicals.

From the $1860 \mathrm{~s}$, the constitutions of both Romania and Serbia rendered their link with the Ottoman Empire fictitious. The guaranteeing powers tacitly accepted the constitutional arrangements in the Balkan principalities and the Ottoman Porte was unable either to protest or to otherwise prevent the new constitutional order.

Favouring the spread of constitutional reforms on the Balkan Peninsula, the aim of

Državopis Srbije 1869: 100-101.

Radović 2013: 27, 29-31. 
the western European countries was to push out the Russian influence even more, to break down that natural relationship which originated in the Russian efforts and pressures on the Ottoman Empire to make significant concessions in order to grant political freedom to its provinces. Being aware of the intentions of the West, Russia protested and responded strongly to the Greek project of the constitution of 1869 and previously also to the Romanian Constitution of 1866. In the case of Serbia, on the other hand, Russia was most moderate, obviously knowing that it was a process that could not be stopped. However, the main objection to Greece and Romania was that these countries went through secular democracy at their own expense. In the Russian view, democracy in the Balkans was a devastating element imported from the West, with the aim to weaken the newly formed and vulnerable states. The danger for Serbia, like Romania and Greece, to fall under the influence of the enemy was imminent in the eyes of Russia. ${ }^{21}$ On the other hand, Vienna especially emphasized that after the new constitutional order Serbia could no longer be considered a Russian outpost in the Balkans, but a factor worthy of respect in the Eastern Question. ${ }^{22}$ In the context of the Russian-Austrian rivalry, the adoption of the Constitution of 1869 was interpreted as the success of the Austro-Hungarian Empire and the defeat of Russia. The Austro-Hungarian and British favouritism and support of the Serbian side in making the constitution were obvious. There were especially strong hopes of a Viennese representative Benjamin Kallay that the new liberal circumstances would weaken the cohesion of Serbia, which would thus blunt the blade of Serbian nationalism directed towards Bosnia and Herzegovina and the destruction of the Ottoman Empire. ${ }^{23}$ Thus, after they returned home, a growing number of young people educated at Western universities started spreading new ideas from the West. Through diplomatic representatives of Western European countries in the Balkans constitutional forms of France, Belgium, indirectly and Great Britain were favoured there for political reasons. While the Western powers supported the new constitutions to replace solutions inspired by the Russian views, Romania and Serbia saw their constitutional systems of the 1860 s as a significant step towards the definitive emancipation from the Ottoman Empire. In his reports, the French consul in Belgrade, Edouard Engelhart, hinted at some predictions according to which the future of the Balkans belonged to Serbia. According to him, Serbia would be the country which would gather South Slavs regardless of any existing disagreement and problems with its neighbours. ${ }^{24}$

While Romania, with its rather moderate constitutional changes, welcomed the 1860 s, in Serbia there was quite a chaos ruling in its political life. A weak progressive opposition and the king were rather powerless and the expression of this impotence was the Constitution of 1889. It granted the right to vote to as many as 450.000 people (about $90 \%$ of adult men); voting became secret and full ministerial responsibilities were introduced, while parliamentary government members were recruited from the parliamentary majority. Already at the first elections it was obvious what such parliamentary system in Serbia would look like in practice. Out of the 117 seats, Radicals won 102 (87.2\%), while in 1893 Radicals

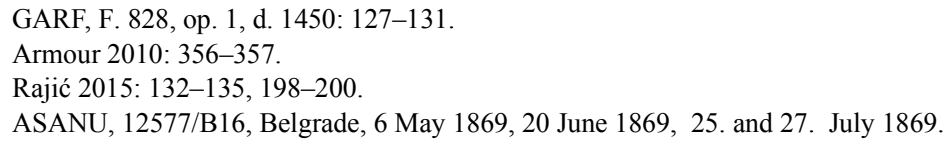


won $88.34 \%$ of votes and entered the Assembly with 126 seats in addition to 10 Progressives. Infiltration into all central institutions (Government, Parliament, Council of State, Court of Appeal and the Court of Cassation, Main Control) and the local authorities (municipalities, counties) placed the Radicals in a position of all-absorbing power. The parliamentary system soon turned into a one-party system. The ruler's prerogatives were reduced to one vote. The institution of the assembly became powerful, because it had a monopolistic position. The institutions of the Government and the Council of State with the Assembly could always outvote the king and impose their will. ${ }^{25}$

The king soon concluded that the French parliamentary system was not for Serbia, because there were people in this country who desired disorganization of the state and its occupation by one party. ${ }^{26}$ The Radicals wanted a state that would be lead by their Party and the people's government because they were a majority. This concept presupposed a party state, because without a solid opposition participating in the representative body, monism in politics was inevitable. The king believed that the right to vote was a privilege that was closely related to the level of general development and elementary literacy of the Serbian society, while the opposition presented it as a basic right of every citizen. The new Constitution of 1901 provided legal security and political freedom and the novelty were the two houses. The Senate consisted of a divided intelligentsia and the Church and Military representatives. According to the Constitution of $1901,72 \%$ of adult males had the right to vote. ${ }^{27}$ The elections were confidential, judicial authority was independent and the municipal government guaranteed. The Constitution only proclaimed the principle of freedom of association and the press, but the extent of those freedoms could be established by subsequent legislation. The king accomplished what he wanted - that the Sovereign, the Senate and the Assembly were equal factors in the legislation. Proposed legislations could be presented by all the legislative factors and the budget was definitely entrusted to the Assembly. This constitution solved the most contentious issues on the Serbian political scene, it determined the centre of the authority and state policy makers by coordinating between the ruler and the Assembly. The king had high hopes in the Senate, a body introduced in Serbia for the first time. "The Senate was as a lightning rod for the ruler because it coordinated hasty decisions of the Assembly, without exposing the ruler," he said. The king believed that establishment of the Senate was the only way to gather the fittest and the most experienced statesmen in the country in one institution, the people who would work without fear of the Assembly. By consciously granting the majority in the Senate to the Radicals, the king showed great political naivety, which he tried to correct by a coup in 1903, just before the time when he and his wife were assassinated in a courtyard on 11 June. ${ }^{28}$ The Constitution of 1889 was restored and the newly elected ruler Petar Karađorđević had to pledge to respect the constitution before coming to Serbia and the role of a ruler was marginalized.

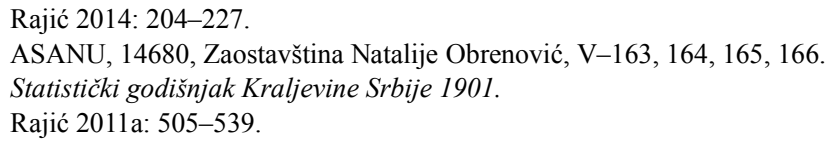




\section{Models and Practice}

Despite the apparent rivalry and the struggle for prestige in the Balkans between the Western European states on the one hand and Russia on the other, we cannot ignore the fact that during the decades of work on establishing legal and constitutional order, the Balkan principalities tried to bring their national constitutional form that could be most suitable for domestic social and political events, traditions and customs. It is obvious that in Romania and Serbia the French Constitutional charters of 1814 and 1830, the French Constitution of 1848 and the Belgian Constitution of 1831 had the main role in creating the constitutional models. The French influence was particularly noticeable in the fields of civil and human rights and political freedoms. In the constitutional ambitions of Serbia from 1835 and in Moldavia and Wallachia from 1848 we can clearly see the influence of the French Declaration of the Rights of Man and its triad "liberty, equality, fraternity". ${ }^{29}$ Also, of great importance was an impact of the Belgian constitution of 1831. As a product of a synthesis between the French and the British constitutional traditions, the Belgian constitution made use of the heritage of the French Charters of 1814 and 1830 and the model of the British monarchy. In the $19^{\text {th }}$ century, the integration of the western models with the 'tradition' was obvious in both Romania and Serbia. ${ }^{30}$

In the widest sense, the role models were taken from constitutional monarchies, where the power of the ruler was significant. When we look at the articles of the French constitutional charter of 1814 and a section about the ruler, it is clear that that part was almost entirely taken into both Romanian and Serbian constitutions. Thus, the constitutional provisions on political freedoms, separation of power and constitutional authority of the ruler were those constitutional entities in which the assumption was obvious. Young monarchies and young dynasties, because of frequent coups and dethronements, had their rulers only as elected figures. Because of that, in terms of the ruler's personality, it was necessary to resort to the constitutional founding of a hereditary principle, lack of responsibility, the sanctity and the supreme command of the army, and participation in legislative and executive authorities. ${ }^{31}$

The Senate was also seen as a safeguard of the ruler from excessively liberal and, in Serbia, leftist demands. In Serbia, however, the Senate could not be formed until the early $20^{\text {th }}$ century and then that body could be filled only by the representatives of political parties, with a small number of university professors and representatives of the clergy and the military. While in France the tax laws could not be proposed in the Assembly, in Serbia, for example, since the first constitution of 1835 no a single tax could be increased or a new one introduced without the consent of the dominantly peasant National Assembly. The French government could be involved in the elections through electoral bodies appointed by the king, but if it did not enjoy the confidence of the parliamentary majority, it had to withdraw. For example, the French king acted upon a ministerial invitation only and the Belgian king

29 The Romanian Constitution from 1866 articles 5 to 30; the Serbian Constitution from 1835 articles 108-131, from 1869 articles 22-53, and from 1889 articles 6-75.

30 Stanomir 2002: ch. 2; Gutan 2013: 231.

31 Temmerman 1952: 342-345. 
could appoint and dismiss his ministers with absolute freedom in his choice. But the King always chose his ministers from the members of the parliamentary majority. ${ }^{32}$ However, the political elite of young principalities had an insufficiently clear perception of the constitutional role of the monarch and other constitutional principles. Because of that, there were some distortions and violations of the constitution in its implementation, which was particularly evident in the case of Serbia. There was a particular confusion between the imported institutions and the Serbian understanding of the constitutional architecture, which rendered a rather incoherent text, where peculiar relationships between the legislative and executive sections were misleadingly depicted. For instance, the Belgian constitution, although not stipulating clearly, in practice applied the parliamentary system which was also adopted in Romania. In Serbia, however, this approach was ignored until a parliamentary constitutional order was introduced by the pressure "from the grassroots", which was, therefore, short-lived (1889-1893). ${ }^{33}$ On the second occasion, in 1903, there was more success, although there was in effect a one-party system since the scarce opposition in the Serbian parliament was unable to dismiss or manage the government majority. The problems regarding the implementation of the parliamentary system were not caused only by the absolutist will of Serbian rulers as it is usually emphasized. The grassroots factor also played an important role.

The Romanian ruler adopted a maxim "the sovereign rules but does not govern". 34 Actually, fixed between constitutional restrictions and consensual work of liberals and conservatives, the Romanian ruler did not have the conditions to strengthen his influence to the extent to which he wanted to. The Romanian society was moving towards a parliamentary democracy step by step. Credits to gradual constitutional development belong to the existence of a classic two-part party system. A deal between the liberals and the conservatives was based on a consensus that excluded any possibility of the prince's personal rule and kept out the masses from the political life. The structure of the society had the potential to carry out a gradual reform. Political and economic development of Romania in the last quarter of the $19^{\text {th }}$ century contributed to the doubling of the bourgeoisie. Out of the six million inhabitants one million belonged to that social stratum. In the mid-century bourgeoisie constituted $17.2 \%$ of the society as opposed to as much as $82.8 \%$ of the rural population. At the end of the century, this ratio remained almost the same $-18.8 \%$ versus $81.2 \%{ }^{35}$ Because of that a stable government was formed, which governed the country for ten years (1878-1888). During that time, Serbia changed nine cabinets. ${ }^{36}$

Conservatives in Romania were mostly made up of landowners, while the middle class was gathered in the Liberal Party in 1875. It was an absurdity that the conservatives were the ones to advocate the parliamentary system. This attitude originated from their real political power and also acted as a protection from anarchy and arbitrariness of the ruler. However, the advantage of the Conservatives during the process of affirmation of political life slowly melted. After two decades, liberals or middle-class (merchants, industrialists and

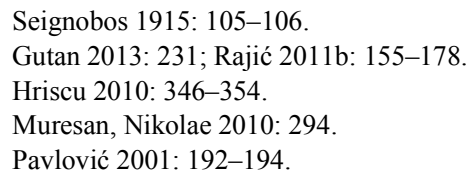


tradesfolk) prevailed in the elections and won the majority in the parliament. A special feature of the Romanian society was an unusual social mobility in the last quarter of the $19^{\text {th }}$ century. In fact, there was no clear line between the large landowners and the wealthy bourgeoisie. It often happened that the old families' properties were owned by bankers and traders, while the landowners themselves became the bourgeoisie. ${ }^{37}$

This process helped the social symbiosis between those factors which actually actively involved government. This was an important fact which indicated that the constitutional development and overall political life of Romania was closely related to the economic and industrial progress: the power belonged to those who were constantly evolving and becoming strong. So there was no pressure from "grassroots" to coerce any temporary solutions. In the established political system everyone worked on the reforms patiently. This referred to the ruler as well, who had a key role in forming the government, but was not directly involved in the bipartisan system, always giving priority to those who offered the necessary and gradual reform.

Unlike Serbia, where the largest social class, the peasantry, was homogeneous, in Romania this stratum was one class. All forms of serfdom were abolished in the period from 1843 to 1856 . From the active agrarian population numbering about 1.5 million, $14 \%$ was landless, $7 \%$ had to lease additional space due to the small size of the property, and as many as $52.5 \%$ had an area of less than five hectares and had to work on large estates, while about $12.3 \%$ were forced to temporary wages. There was a small group of rural "bosses", about $2.5 \%$, who participated in establishing export, $85 \%$ out of which accounted for grain. Also, regardless to its rapid economic development during the $19^{\text {th }}$ century Romania was predominantly an agrarian country. Arable land was doubled by the end of the century and the residents of Romania had up to $70 \%$ more land than their neighbouring Serbia or Bulgaria. However, farmers in Serbia worked less and because of that they lived more easily than those in Romania. ${ }^{38}$ In mid $19^{\text {th }}$ century, due to many Christian holidays, only about a third of the days in the year were working days (115). The number of working days increased steadily, but in Serbia the process was much slower than in Romania. This reflected on the implementation of the Constitution of 1889. Despite its 'modernity' it could hardly be implemented in a more egalitarian society in which the bourgeoisie was four times smaller than in Romania, where literacy in cities was $50 \%$ and the average literacy in the country was only about $14.7 \%$. In Serbia at the beginning of the 1880 s, there were about 1.5 million people per 49,000 square kilometers and that number increased to 2.4 million at the end of the century. Villages accounted for the $87 \%$ of the population and the cities and towns for $12.49 \%$ of the total population. ${ }^{39}$ Craftsmen made up $6.54 \%$ of the population, merchants $4.63 \%$, while "other occupations" which should include also magistrates and "freelancers" numbered $4.72 \%$ of the population. At the end of the $19^{\text {th }}$ century, the urban population counted just over 350,000 people (14.08\%). The occupation of $90.43 \%$ of the population was farming. In the last decade of the $19^{\text {th }}$ century even in the cities almost $21.5 \%$ of the urban population lived off farming. The number of civil servants was $1.35 \%$,

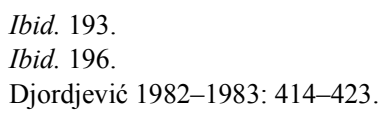


merchants and innkeepers $1.97 \%$, craftsmen $3.15 \%$, servants and labourers $1.26 \%$, priests $0.21 \%$ and other occupations $1.63 \%$. In 1900 Serbia reached the general population density of 51.6 inhabitants $/ \mathrm{km}^{2}$, outnumbering the European average of 37 inhabitants $/ \mathrm{km}^{2}$ and the average of the surrounding countries, such as Romania, Bulgaria, Greece, Turkey and Montenegro. ${ }^{40}$ So the population was increasing annually by 12 to $15 \%$, but arable land remained the same, which lead the country into backwardness and impoverishment of the peasantry. The basic land tax had not been increased for decades and was even decreasing. Industrialization was not implemented and on the eve of the $19^{\text {th }}$ century, there were barely four thousand workers in the whole country. ${ }^{41}$ Foreign capital was out of the country, because there was no favourable business climate. ${ }^{42}$ The financial and political problems were great - the national debt of 300 million dinars in 1895 increased to 414 million francs by the end of the $19^{\text {th }}$ century, the political fragmentation of the scarce intelligence and recruiting the peasant masses in politics rendered King Milan Obrenović's struggle against radicalism unsuccessful. That struggle ended with the destabilization of the king (1889) and an even stronger destabilization of the state. Foreigners in Serbia noticed that the king's personality was not respected enough. "This is a half-European - half-eastern country, people disrespecting democracy, undisciplined people, and without respect for the hierarchy," was a testimony of an expat. ${ }^{43}$

In the meantime, Romania's middle class was rapidly maturing and its maturity manifested in the adoption of economic trends from the West. In the era of industrial protectionism after 1886, it stimulated domestic production and rapidly developed industry under the state protection. Such development was not characteristic of Serbia, where the society still waited to be helped by the state to take over the initiative. The state helped some individuals and the choice was made according to political and dynastic connections. Serbia stimulated ventures of foreign contractors as well as people who were professionally and financially ready to invest in the development of industry. While the state provided good conditions, individual risk taking and lack of investments could not yield any lasting results. All in all, Serbia failed to join the main European course of development, recording constant stagnation. $^{44}$

These differences in the social structure and the pace of economic development had great influence, so similar constitutional models in two different socio-political systems had different applications yielding different results. As for the foreign impact, Serbia and Romania shared the same fate by the beginning of the First World War. Both were forced to endure a lot of pressure because of the Austro-Russian rivalry, which certainly compelled them to accept the West European influences more than they wanted, or better still, more than they were prepared for.

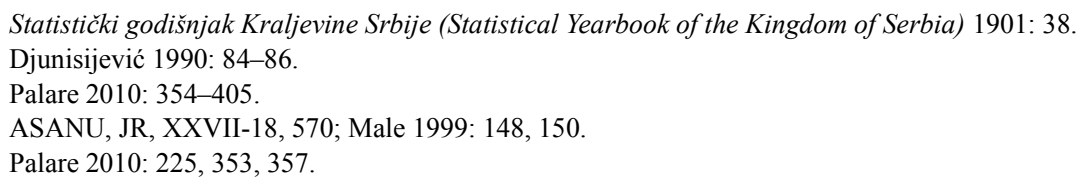




\section{REFERENCES:}

Archive of the Serbian Academy of Sciences and Arts (Arhiv Srpske akademija nauka i umetnosti ASANU)

State Archive of the Russian Federation (Gosudarstvennyi Arkhiv Rossiiskoi Federatsii - GARF)

Armour, I. D. 'Killing Nationalism with Liberalism? Austria-Hungary and the Serbian Constitution of 1869', Diplomacy and Statecraft, 21/3, 2010, 346-367.

Carp, R. 'Governmental responsibility and parliamentary irresponsibility in the Romanian constitutional tradition', in M. Czobor-Lupp and J. S. Lupp (eds.), Cultural heritage and contemporary change, Eastern and Central Europe. Moral, Legal and Political Values in Romanian Culture / Washington DC: The Council for Research in Values and Philosophy 2002, 99-108.

Djordjević, D. 'Srbija i srpsko društvo 1880-ih godina', Istorijski časopis, 29-30, 1982-1983, 414423. (Serbian Cyrillic)

Djunisijević, R. Osnivanje industrijskih preduzeća i razvoj industrije u Srbiji do 1918, Beograd: BIGZ, 1990.

Državopis Srbije, Beograd: Knjažesko-srpska pečatnja, 1869.

Gutan, M. 'The Challenges of the Romanian Constitutional Tradition. Between Constitutional Transplant and Institutional Metamorphoses', Journal of Constitutional History / Giornale di Storia Costituzi, 25, 2013, 223-252.

Hriscu, M. 'Constitutia Romanesca de la 1866. Modernism si Spirit European', Anuarul Universitatii „Petre Andrei” din Iasi / Year-Book „Petre Andrei” University from Iasi, Fascicula: Asistenta Sociala, Sociologie, Psihologie / Fascicle: Social Work, Sociology, Psychology, vol. 1, issue 5, 2010, 346-354.

Kellogg, F. The road to Romanian independence, West Lafayette: Purdue Univesrity Press, 1995.

Laurentiu, S. 'Modernization in the middle of the 19th century in the Romanian principalities: project and realization', in M. Czobor-Lupp and J. S. Lupp (eds.), Cultural heritage and contemporary change, Eastern and Central Europe. Moral, Legal and Political Values in Romanian Culture / Washington DC: The Council for Research in Values and Philosophy 2002, 177-200.

Ljušić, R. Kneževina Srbija 1830-1839, Beograd: Zavod za udzbenike, 2004. (Serbian Cyrillic)

Ljušić, R. Orijentalni novinar, evropski političar Dimitrije Davidović (1789-1838), Beograd: Politika NM, Tanjug, 2006. (Serbian Cyrillic)

Male, A. Dnevnik sa srpskog dvora 1892-1894, Beograd: Clio, 1999. (Serbian Cyrillic)

Muresan, M., Nikolae, M. 'Economic mentalities - cause or effect for today's values in Romanian business higher education? A historical perspectives', Anale stiintifice ale Universitatii Alexandru Ioan Cuza, 2010, 291-299.

Pavlović, S. Istorija Balkana, Beograd: Clio, 2001. (Serbian Cyrillic)

Palare, M, Balkanske privrede oko 1800. do 1914. godine. Evolucija bez razvoja, Beorgad: Službeni glasnik, 2010. (Serbian Cyrillic)

Popović, M. Sudstvo u Kneževini Srbiji 1838-1869, Beograd: Filozofski fakultet PhD, 2014. (Serbian Cyrillic)

Radović, D. Jovan Ristić i liberali u Srbiji pre osnivanja Narodne liberalne stranke (1858-1881), Beograd: Filozofski fakultet MA, 2013. (Serbian Cyrillic)

Rajić, S. (a) 'Nova politička zajednica i vlade MIhaila Vujića 1901/2. godine', Istorijski časopis, 60, 2011, 505-539. (Serbian Cyrillic)

Rajić, S. (b) 'Nikola Krstić o vladavini Aleksandra Obrenovića', Srpske studije/Serbian Studies, 2, 2011, 155-178. (Serbian Cyrillic)

Rajić, S. 'Parlamentarism v Serbii: pervye opyty i problemy', Gosudastvennoe upravlenie. 
Elektronnyi vestnik, 44, 2014, 204-227. (Russian Cyrillic)

Rajić, S. Spoljna politika Srbije izmedju očekivanja i realnosti (1868-1878), Beograd: Srpska književna zadruga, 2015. (Serbian Cyrillic)

Seignobos, Ch. A political history of contemporary Europe since 1814, London: William Heinemann, 1915.

Stănescu, L. 'Progressive traditions of romanian constitutionalism', Codrul Cosminului, 13, 2007, $167-188$.

Stanomir, I. 'The temptation of the west: The romanian constitutional tradition', in M. Czobor-Lupp and J. S. Lupp (eds.), Cultural heritage and contemporary change, Eastern and Central Europe. Moral, Legal and Political Values in Romanian Culture / Washington DC: The Council for Research in Values and Philosophy 2002, 75-97.

Temmerman, J. A. 'Constitutional customs in Belgium', Parliamentary affairs, 4, 1952, 342-345.

Vinogradov, V. N. The Double-headed Russian Eagle in the Balkans: 1683-1914, Moscow: Indrik, 2010. (Russian)

\section{СУЗАНА РАЈИТ}

Универзитет у Београду, Филозофски факултет

Одељење за историју

\section{УСТАВНА ОРГАНИЗАЦИЈА СРБИЈЕ И РУМУНИЈЕ У ХІХ ВЕКУ: УНУТРАШЫЕ ПОТРЕБЕ И СПОЉАШЫИ УТИЦАЈИ - КОМПАРАТИВНА АНАЛИЗА}

\section{Резиме}

Циљ рада је анализа два значајна чиниоца у процесу организације Србије и Румуније у XIX веку: спољних фактора и унутрашњих друштвено-политичких околности. Из тог разлога уставни модели и врсте имплементације су значајан део овог рада. Ослањајући се на аналитичке и компаративне методе у раду илажемо сличности и разлике у процесу конституционализације у овом делу Балкана.

Кључне речи: Устави, парламентарни систем, Србија, Румунија, западни утицаји, унутрашња политика. 